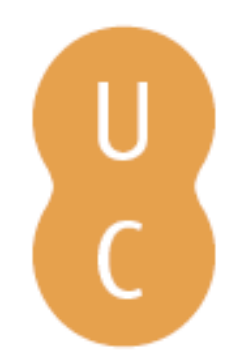

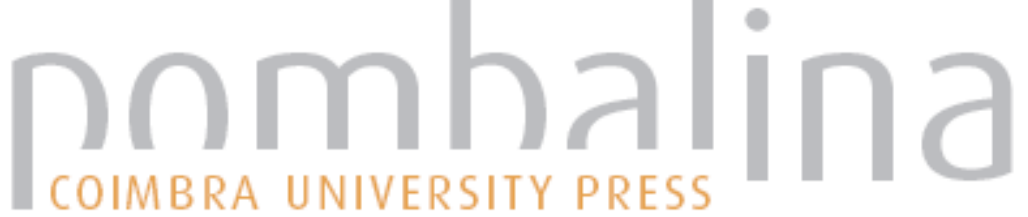

\section{Sudden death from Cryptococcal encephalitis}

Autor(es): $\quad$ Papi, L.; Forni, D.; Castagna, M.; Becherini, F.

Publicado por: Imprensa da Universidade de Coimbra

URL

persistente: URI:http://hdl.handle.net/10316.2/31735

DOI: $\quad$ DOI:http://dx.doi.org/10.14195/978-989-26-0173-1_71

Accessed : $\quad$ 26-Apr-2023 12:52:21

A navegação consulta e descarregamento dos títulos inseridos nas Bibliotecas Digitais UC Digitalis, UC Pombalina e UC Impactum, pressupõem a aceitação plena e sem reservas dos Termos e Condições de Uso destas Bibliotecas Digitais, disponíveis em https://digitalis.uc.pt/pt-pt/termos.

Conforme exposto nos referidos Termos e Condições de Uso, o descarregamento de títulos de acesso restrito requer uma licença válida de autorização devendo o utilizador aceder ao(s) documento(s) a partir de um endereço de IP da instituição detentora da supramencionada licença.

Ao utilizador é apenas permitido o descarregamento para uso pessoal, pelo que o emprego do(s) título(s) descarregado(s) para outro fim, designadamente comercial, carece de autorização do respetivo autor ou editor da obra.

Na medida em que todas as obras da UC Digitalis se encontram protegidas pelo Código do Direito de Autor e Direitos Conexos e demais legislação aplicável, toda a cópia, parcial ou total, deste documento, nos casos em que é legalmente admitida, deverá conter ou fazer-se acompanhar por este aviso.

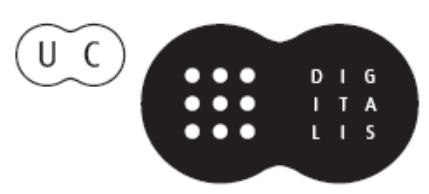




\section{Duarte Nuno Vieira Anthony Busuttil \\ Denis Cusack • Philip Beth}
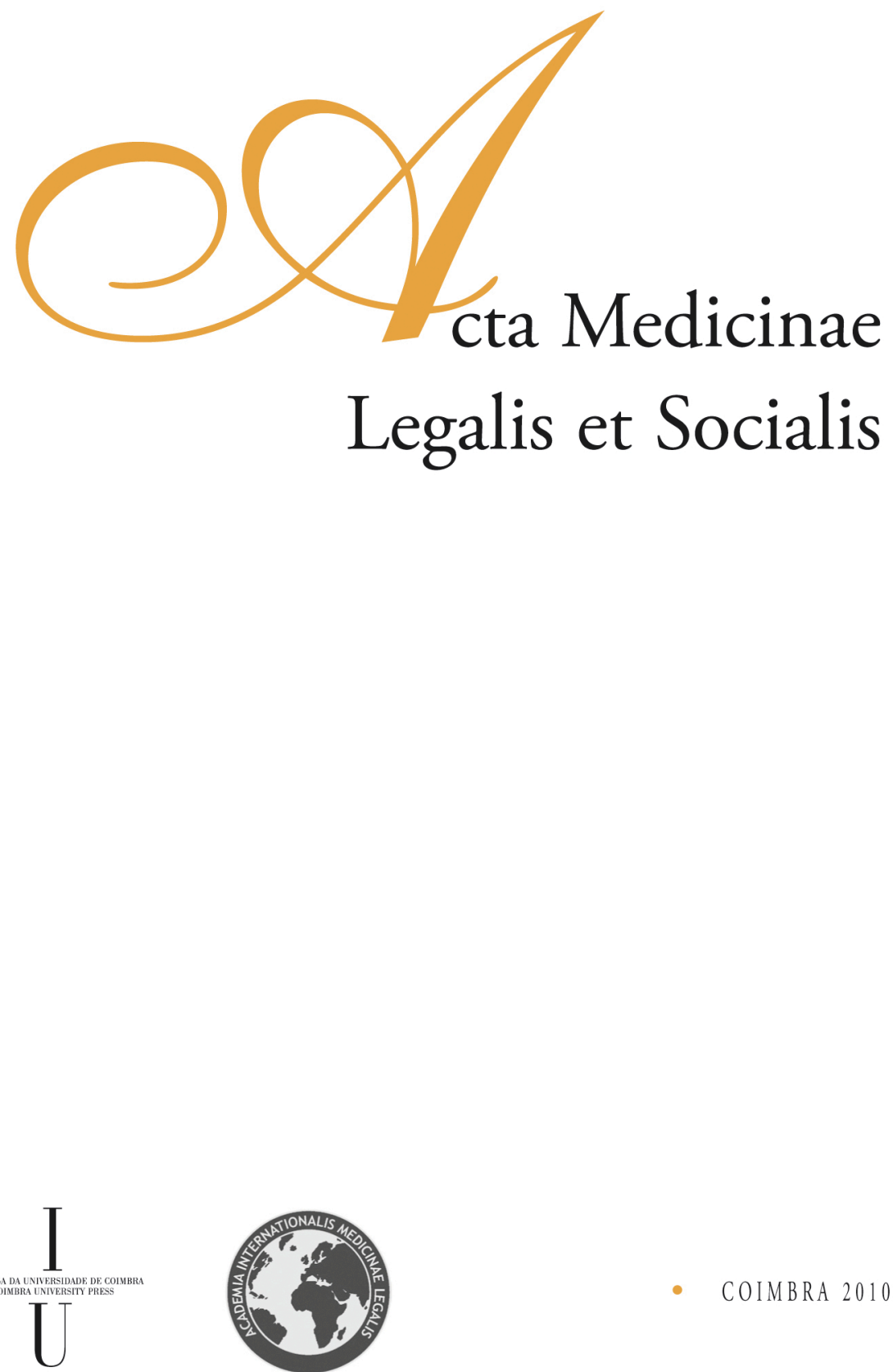
L. Papi ${ }^{1}$, D. Forni ${ }^{1}$, M. Castagna ${ }^{2}$, F. Becherini ${ }^{2}$.

${ }^{1}$ Department of Legal Medicine, University of Pisa, Italy

${ }^{2}$ Department of Pathological Anatomy, University of Pisa, Italy

\title{
SUDDEN DEATH FROM CRYPTOCOCCAL ENCEPHALITIS
}

\begin{abstract}
We describe a case of sudden death from Cryptococcus-related encephalitis of a young man with misdiagnosed AIDS-Syndrome. The patient was admitted twice in Hospital in the weeks before the death and he was also visited at home just the same day he died, but clinical suspect of encephalitis was completely failed, despite he'd complained neurological symptoms, with subsequent medico-legal implications concerning medical malpractice.
\end{abstract}

\section{Introduction}

Cryptococcal meningo-encephalitis (CME) is generally uncommon (1/1000 per years in U.S.A.) but AIDS outbreak has caused its dramatic worldwide increase in recent years. CME represent a typical opportunistic infections associated with AIDS, occurring about in $6 \%$ to $8 \%$ of AIDS patients $(1,2)$ even if rare cases are observed also in immunocompetent individuals $(3,4,5,6)$.

Therapy is based on antifungal drugs but the prognosis is dramatically poor.

\section{Case report}

A 35-year-old man, addicted to heroin in the past, was found dead in bed while he was spending a few days at friend's home. For many weeks before, he had been complaining of disease with nausea, vomiting, headache, dizziness.

He went to the Hospital in E.R. twice in the early period before death; the first time (13 days before the death) no signs of meningism were found at medical examination; during the admission to the Hospital the patient had a lipotymic crisis, but he was discharged a few minutes later with diagnosis of lypotimia flu-syndrome related. After six days he was transported again to the Hospital, complaining of lost of consciousness, vomiting, asthenia and cold sweat: it was performed a physical and electrocardiographyc examination, negative for abnormalities, and the patient was discharged with the same diagnosis.

During the following week he has been continuously staying in bed for a severe weakness; after the onset of a convulsive crisis the doctor who examined the patient at 
home attributed the symptom to oppioid withdrawal syndrome and did not arrange hospitalisation. The day after the man was found dead in the bed.

The medico-legal investigation revealed remarkable brain swelling (Fig.1,2) associated with pulmonary congestion. Histological examination of brain specimens showed micotic clusters in meninges, cortex and cerebellum (Fig. 3,4), not associated with significant inflammatory cells response. Laboratory tests indicating a meningoencephalitis from Cryptococcus neoformans and virologic examination from liquor and brain specimens revealed also the presence of Epstein-Barr and BK viruses while blood examination revealed HIV.

\section{Discussion}

Cryptococcal meningo-encephalitis is the most common fungal infection of the central nervous system. It is rare in immunocompetent hosts, but it represents the most important life-threatening fungal disease in patients affected by AIDS (7), with a prevalence of 2-10\% among HIV-positive patients in Western Europe and U.S.A. Cryptococcosis is often the initial AIDS-defining illness (about $60 \%$ of patients in Italy (8) and France (9), 30-40\% in U.S.A.(10)).

Clinical manifestations evolve chronically with severe headache, deficit of cranial nerves (aphasia, hearing loss, visual deficit), seizures, cerebellum's signs, and increasingly intracranial hypertension, but signs of neurological infection are manifest only in one third of patients.

The impact of increased intracranial pressure on early mortality of patients with AIDS-associated cerebral Cryptococcosis has been stressed and the guidelines of the Infectious Diseases Society of America recommended that patients with an opening pressure $>250 \mathrm{mmH} 20$ must be treated with mechanical (11) and pharmacological cerebrospinal fluid drainage (12). From a Pathological point of view, AIDS-related CME differs from other neurological infections for the lack of inflammatory response and mortality is due to intracranial hypertension, with subsequent brain swelling and herniation produced by mechanical barrier in the arachnoids' villa caused by clusters of mycetes.

Cryptococcus is generally considered difficult, if not impossible, to eradicate in AIDS patients, thus requiring life-long antifungal therapy, based essentially on amphotericin B and fluconazole (13). Most of the available evidences suggest that amphotericin-B-base therapy represent the gold standard and the combination of an amphotericin B preparation plus flucytosine should be regarded as the best initial treatment, being the more effective treatment to obtain rapid clearance of the fungus from cerebrospinal fluid, which is probably the best surrogate marker for ultimate successful therapy (14). Because of the toxicity of amphotericin, after initial treatment, it is necessary to modify therapy switching to fluconazole, which instead is less efficient in eradicate the fungi.

Untreated Cryptococcal meningitis is uniformly fatal within a relatively short period of time and the prognosis of Cryptococcal meningitis is still poor even in patients who receives early and correct therapy (15), considering that mortality rate is about $50 \%$. In our case, the pathology affecting the central nervous system has been further 
aggravated by the simultaneous infection from Epstein-Barr and BK viruses, opportunist agents often responsible for meningo-encephalitis in AIDS patients $(16,17,18)$.

Even considering these dramatic prognosis, the lack of adequate instrumental and radiographic investigations despite the severe symptoms that affected the man before the death, has determined medico-legal implication concerning the case submitted to our study, in order to asses medical responsibility in failing the correct diagnosis.

Cryptococcal encephalitis represents a common complication among patients infected with the human immunodeficiency virus and it must be kept in mind the possibility of a Cryptococcal neurological infection in those patients with evidence of AIDS, being an early treatment the only resource for a life-threatening outcome.

\section{References}

[1] CURRIE B.P., CASADEVALL A, Estimation of the prevalence of Cryptococcal infection among HIV infected individuals in New York City, Clin Inf Dis, 1994;19:1029-1033.

[2] CHUCK S.L., SANDE M.A., Infections with Cryptococcus neoformans in the acquired immunodeficiency syndrome, N. En. J. Med., 1989, 321:794-799.

[3] ZAHRA V, AZZOPARDI C. SCOTT G, Cryptococcal meningitis in two apparently immunocompetent Maltese patients. Mycoses, 2004; 47, 168-173.

[4] BRETAUDEAU K ET AL, Cryptococcal meningo-encephalitis in an apparently immunocompetent patient, Rev Neurol (Paris). 2006 Feb;162(2):233-7.

[5] THOMPSON H.J., Not your "typical patient": Cryptococcal meningitis in an immunocompetent patient, J Neurosci Nurs. 2005 Jun;37(3):144-8.

[6] CAMPISI D., TUMMINELLO A., BUVONA A., LISTI F., A rare case of Cryptococcal meningitis unrelated to AIDS, Recenti Prog Med. 2000 Jan;91(1):16-9.

[7] AGUIRREBENGOA L, MONTEJO M, PRIETA R, UTERGA J, GAZTELURRUTIA L, ARCE MD, AGUIRRE C. Cryptococcal meningitis and AIDS. Clinical description of 10 patients, Enferm Infect Microbiol Clin. 1992 Feb;10(2):97-102.

[8] ANTINORI S. ET AL., Cryptococcus neoformans infection in a cohort of Italian patients: natural history, early prognostic parameters and autopsy findings, Eur J Clin MIcrobiol Infect Dis 2001;20:711-717.

[9] DARRAS-JOLY C, CHEVRET S, WOLFF M, MATHERON S, LONGUET P, CASALINO E, JOLY V, CHOCHILLON C, BEDOS JP, Cryptococcus neoformans infection in France: epidemiologic features of and early prognosis parameters for 76 patients who where infected with HIV, Clin Inf Dis, 1996;23:369-376.

[10] ZUGER A, LOUIE E, HOLZMAR S, SIMBERKOFF MS, RAHAL JJ, Cryptococcal disease in patients with the acquired immunodeficiency syndrome, Ann Int Med 1992;326:83-89.

[11] ANTINORI S, RIDOLFO AL, GIANELLI E, PIAZZA M, GERVASONI C, D'ARMINIO MONFORTE A, The role of lumbar puncture in the management of elevated intracranial pressure in patients with AIDS-associated Cryptococcal meningitis, Clin Inf Dis, 1991;13-64-67.

[12] GRAYBILL J.R., SOBEL J, SAAG M, van der HORST C, POWDERLY W, CLOUD G, RISER L, HAMILL R, DISMUKES W and NIAD MYCOSES STUDY GROUP and AIDS COOPERATIVE TREATMENT GROPOUS, Diagnosis and management of increased intracranial pressure in patients with AIDS and Cryptococcal meningitis, Clin Inf Dis, 2000;30:47-54. 
[13] LARSEN RA, BAUER M, THOMAS AM, GRAYBILL JR., Amphotericin B and fluconazole, a potent combination therapy for cryptococcal meningitis, Antimicrob Agents Chemother. 2004 Mar;48(3):985-91.

[14] POWDERLY WG, Antifungal treatment for cryptococcal meningitis, Int Med J, 2006;36:404-405.

[15] BICANIC T, HARRISON TS. Cryptococcal meningitis, Br Med Bull. 2005 Apr 18;72:99118.

[16] VOLPI A, Epstein-Barr virus and human herpesvirus type 8 infection of the central nervous system, Herpes 2004, 11(2):120-127.

[17] GARAVELLI PL, BOLDORINI R, BK virus encephalitis in an HIV-seropositive patient. Preliminary data, Recenti Prog Med. 2002 Apr;93(4):247.

[18] CUBUCKU-DIMOPUlO O, GRECO A, KUMAR A, KARLUK D, MITTAL K, JAGIRADAR J, BK Virus infection in AIDS, Am J Surg Path, 2000;24:145-153.
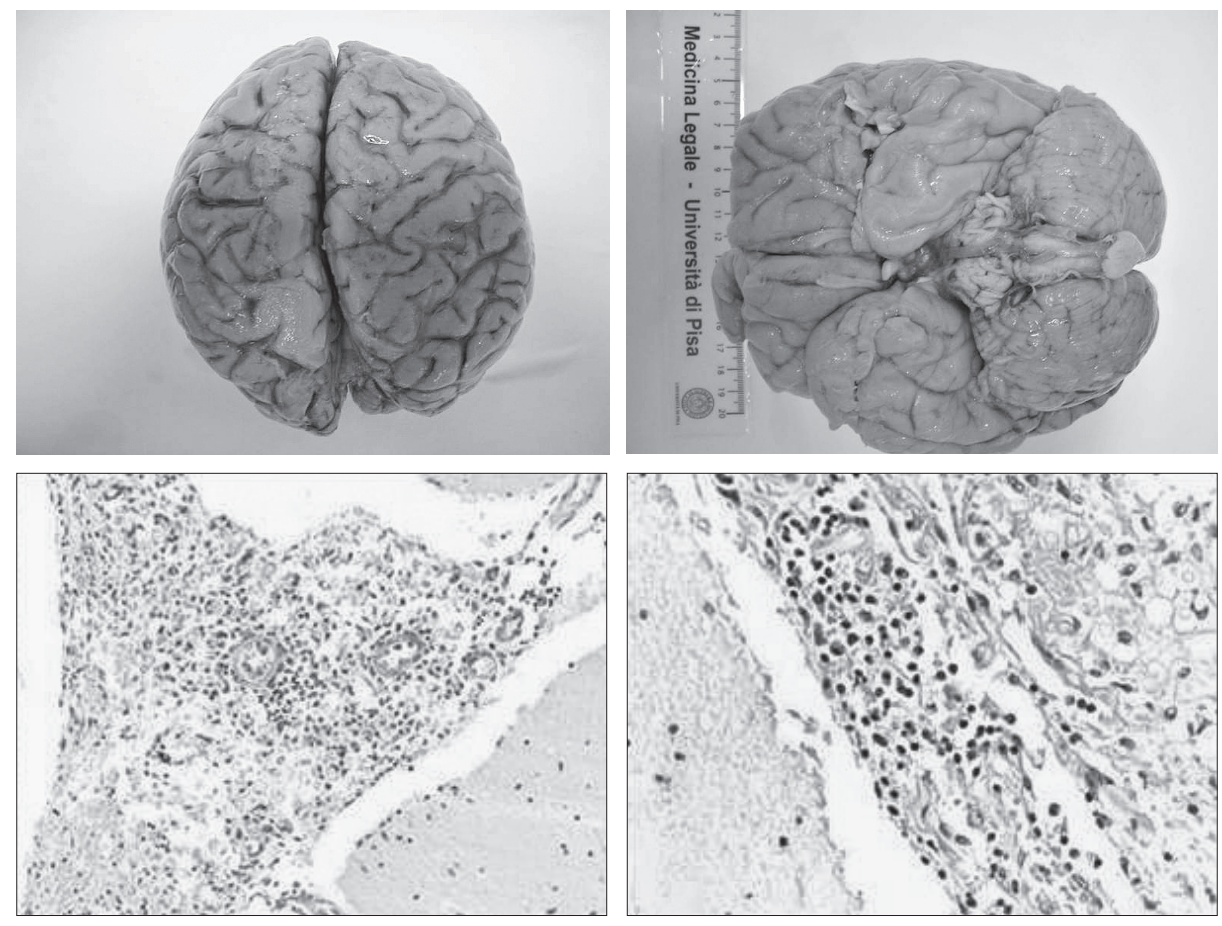